\title{
Geological Context Mapping of Batouri Gold District (East Cameroon) from Remote Sensing Imagering, GIS Processing and Field Works
}

\author{
Bissegue Jean-Claude ${ }^{1}$, Tchameni Rigobert ${ }^{1}$, Etouna Joachim² ${ }^{2}$, Fosso Tchuente Périclex ${ }^{1}$, \\ Danra Moh Guela Guy Basile ${ }^{1}$
}

${ }^{1}$ Department of Earth Sciences, Faculty of Science, University of Ngaoundéré, Ngaoundéré, Cameroon

${ }^{2}$ National Institute of Cartography (INC), Yaounde, Cameroon

Email: jeanclaudebissegue@yahoo.fr

How to cite this paper: Jean-Claude, B., Rigobert, T., Joachim, E., Périclex, F.T. and Basile, D.M.G.G. (2019) Geological Context Mapping of Batouri Gold District (East Cameroon) from Remote Sensing Imagering, GIS Processing and Field Works. Journal of Geographic Information System, 11, 766-783.

https://doi.org/10.4236/jgis.2019.116046

Received: November 12, 2019

Accepted: December 24, 2019

Published: December 27, 2019

Copyright $\odot 2019$ by author(s) and Scientific Research Publishing Inc. This work is licensed under the Creative Commons Attribution International License (CC BY 4.0).

http://creativecommons.org/licenses/by/4.0/

\begin{abstract}
The Batouri area is located in the Adamawa-Yade domain in East Cameroon region, and has a high geological potential as a host for gold deposits. It is covered by thick forest where outcrops are sometime scarce. The purpose of this study is to generate and combine different geological information which makes up the specificity of the Batouri gold District, in order to contribute to the better knowledge of its geological setting. From satellite imageries, GIS tools and field data; lithological units, lineament and density maps have been dressed at regional-scale of $1 / 400.000$. The mapping has enabled the discovery of spatial and topologic relationships between shear zones, lineaments, gold occurrences and often mineralized granitic intrusions. According to the field data, lithological and lineament maps, the lithology of the Batouri gold District is characterized by alkali granitoids (tonalite, granodiorite, syenomonzo-granite, alkaline granite) hosted by orthogneisses and migmatites as gold mineralization hosts; while the lineaments show a major shear zones trending NE-SW defined by presence of mylonites. The shear zones crosscut all lithologies, mostly granodiorite where majority of gold occurrences is observed; locally, nearest these shear zones, rocks are transformed to the mylonites and gold is concentrated along. From density map, it is shown that the high gold mineralization zone corresponds to highest lineaments density. All those data suggest that gold mineralization in the Batouri district is controlled by tectonic and lithology. It is conclusive that Batouri gold deposit is epigenetic gold set emplaced in orogenic setting, during the post-collisional stage of the Central African Fold Belt (CAFB) and the Congo Craton (CC).
\end{abstract}

\section{Keywords}

Mapping, Remote Sensing, Landsat 8 OLI, SRTM, GIS, Batouri Gold District 


\section{Introduction}

The lithologic and structural studies are the starting issues to evaluate the spatiotemporal distribution of ore bodies in a landscape in each well-known area. During the last decades, many works have been carried out in the Batouri gold mining area focusing on the geology and geochemical aspects of lode gold mineralization [1]; on the sulphide microchemistry and hydrothermal fluid evolution in quartz veins [2]; on the lode gold mineralization [3], on the geochemistry and geochronology [4], on the investigation of the reliability of anomaly, and also on the ascertainment of the nature of gold distribution within the soil horizons [5], on the determination of the distribution of the area of likely trap mineralization or fluid flow from the gravity data [6]. However, all those studies are concentrated in Kambele site and its surroundings; none is done at regional-scale (municipality) allowing the natives to master their geological resources. Nevertheless, the artisanal mining sites are found everywhere through the study area. Thus, thick forest cover, scarcity of outcrops, lateritic cover, an inaccessible landscape, lack of lithologic details and insecurity are the major hindrances. To overcome these limitations, remote sensing offers a set of tools to improve the location of lithological boundaries and allows the mapping of lineaments with precision.

For more than a century, Remote Sensing using vegetation and drainage pattern as indicators has been long used for its potential in the discrimination of hidden lithological units and fractures in geological studies and mining exploration [7]. As far as, GIS is well known for its performances in compilation of multisource data layers.

In this work, we used the Landsat 8 OLI and SRTM (Shuttle Radar topography Mission) images data combined to the field observations and previous works in GIS to produce geological data such as main lithological facies, structural lineaments and density maps enabling the contribution to the better knowledge of geological setting of the Batouri gold District at East region of Cameroon.

\section{Localization and Geological Setting of the Batouri Gold District}

The study area is bounded between latitude $4^{\circ} 15^{\prime}$ and $4^{\circ} 50^{\prime}$ North and longitude $13^{\circ} 58^{\prime}$ and $14^{\circ} 60^{\prime}$ East and covers a surface area of $3888 \mathrm{Km}^{2}$. Batouri town is situated about $90 \mathrm{~km}$ northeastern of Bertoua and it is accessible through lateritic road (Figure 1).

The Batouri area is part of the Adamawa-Yadé Domain (AYD) of the Pan African fold belt in Cameroon. According to [8] the Adamawa-Yade domain extends eastwards from central Cameroon into the Central African Republic where it is known as the Yade massifs (Figure 2(a)). In Cameroun, Adamawa-Yadé domain is bounded to the north by the Tchollire Banyo shear zone and to the south by Sanaga shear zone towards the Yaoundé domain. Inside, the main faults and shear-zones include the Sanaga fault (SF), the Central Cameroon 
shear zone (CCSZ) and the Mayo Nolti shear zone (MNSZ). Particularly, the Central Cameroon shear zone and the Sanaga fault are well investigated in Mayo Dana-West of Tibati and Bafia regions respectively [9] [10] [11]. Along the ENE-WSW trending Central Cameroon shear zone and his Sanaga shear fault relay, kinematic analysis show an earlier D2 sinistral transpression followed by a D3 dextral shear movement during Pan-African Orogeny. The AYD is dominated by 640 - $610 \mathrm{Ma}$, syn- to late-collisional high-K calc-alkaline granitoids (Figure 2(b)). These granitoids intrude high-grade gneisses that represent a $\mathrm{Pa}$ laeoproterozoic basement, which was likely dismembered during the Pan-African orogeny [8] [12] [13]. The rocks of the AYD are classified into three main groups [12] [14]: 1) large supracrustal blocks of Palaeoproterozoic metasedimentary rocks and orthogneiss with assimilated Archean crust similar to the Ntem Complex, 2) 640 - $610 \mathrm{Ma}$ syn- to late-tectonic granitoids of transitional composition and crustal origin, and 3) 612 - $600 \mathrm{Ma}$ low-to medium-grade metasedimentary and metavolcaniclastic rocks. The geology of Batouri is particularly dominated by syn- to late tectonic granites locally crosscut by systems of shear zones ([15]; Figure 2(c)).

Moreover, newly published interpretations based on field observations, petrological, geochemical and geochronological data suggest that 1) the Adamawa-Yadé domain represents an Archaean/Palaeoproterozoic microcontinent, which was detached from the northern margin of the Congo craton in the early Neoproterozoic, but became re-accreted together with the Mayo Kebbi (magmatic) arc during the Pan-African orogeny [16] 2) the Tcholliré-Banyo Shear Zone, at the northern edge represents the exhumed mid- to lower part of the former orogenic root of the Central Africa Orogenic Belt that has undergone partial melting, lateral flow and pan-African (650 and $580 \mathrm{Ma}$ ) intrusion of mafic to felsic calc-alkaline magmas [17]. It has been intruded by many Pan-African granitic plutons [18].

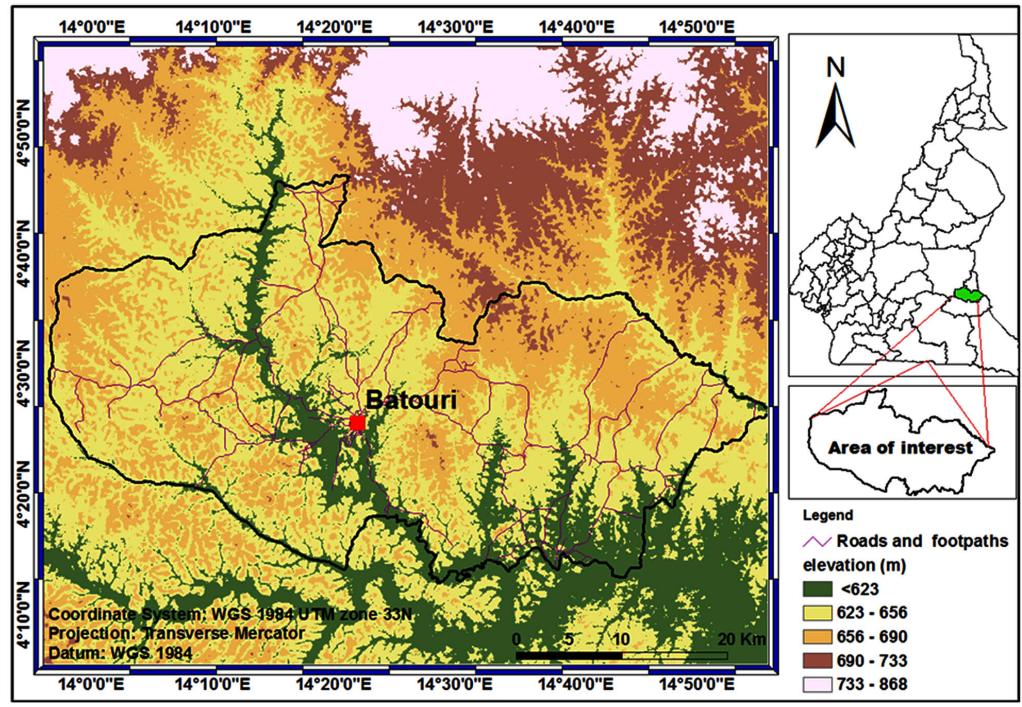

Figure 1. Area of interest edited using DTM data. 


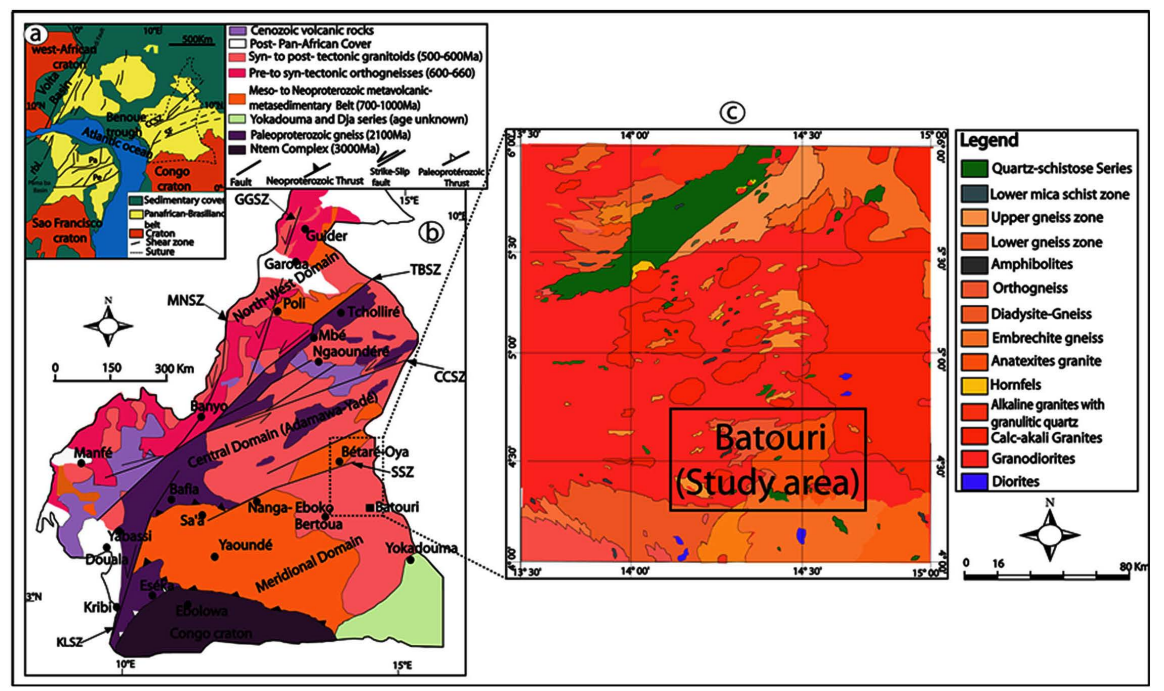

Figure 2. (a) Geological sketch map of west-central Africa and north-east Brazil with cratonic masses and the Pan-African-Brasiliano provinces belt in west-Gondwana; modified from from [19] [20]. Pa: Patos shear zone, Pe: Pernambuco shear zone. Dashed outline roughly marks the state boundary of Cameroon. (b) Geological sketch map of Cameroon showing from the major lithotectonic domains (After [19] [21]). TBSZ: Tcholliré-Banyo shear zone, CCSZ: Central Cameroon shear zone, SF: Sanaga fault, GGSZ: Godé-Gormaya shear zone, MNSZ: Mayo Nolti shear zone, RLSZ: Rocher du Loup shear zone. (c) Geologic map of Batouri east, sheet No NB.33 S.W. E.31 (modify from [15]).

\section{Methods}

\subsection{Remote Sensing Data Set}

To carry out this study a set of Landsat 8 OLI (Operational Land Imager) and SRTM (Shuttle Radar Topography Mission) images of the Endeavour space shuttle were used. A total of two OLI and SRTM scenes 184-57 and 183-057 Path/Row covering the study area were obtained from the U.S Geological Survey website of Maryland University. Their characteristics are as follows: 1) The period of acquisition was December 2018 which corresponds to the dry season, 2) the Landsat image shows clouds SW of study area; 3) the spatial resolution is 30 $\mathrm{m}$, 4) the data are georeferenced to Universal Transverse Mercator (UTM), World Geodetic system 1984 (WGS 84) zone 33N, 5) they are in Geotiff format. The analysis of the different resulting maps was made using Envi 5.1 and ArcGIS 10.2.2.

\subsection{Data Pre-Processing}

\subsubsection{Mosaicking and Subsetting}

Mosaicking is the merging of two or more images just to form a single. It was required because the study area is covering more than one image. Both scenes 184-57 and 183-057 Path/ Row of Landsat and SRTM were merged and the area of interest was subsetted (Figure 3).

\subsubsection{Stretching}

The resulting image of mosaicking and subsetting step was stretched; the con- 
trast was improved manually by the interactive stretching of Gaussien type. The objective here is to increase the perception of the image by improving its visual quality, in order to highlight certain elements that characterize the geology namely faults and discontinuities.

\subsection{Data Processing}

The methodology used was based on Remote Sensing and GIS approach. The main steps of the methodological approach carried out, are presented in the flowchart shown below (Figure 4).

\subsubsection{Lithological Study}

Lithological formations were discriminated using the band color composition, PCA classification, prewitt filter and drainage pattern approach.

\section{1) Band color composite}

The Band color composite was applied to the seven first bands $(1,2,3,4,5,6$ and 7) with the same resolution $(30 \mathrm{~m})$ of the Landsat 8 OLI stacked image, by assigning band 5 to the primary color red (R), band 4 to the green $(\mathrm{G})$ and band

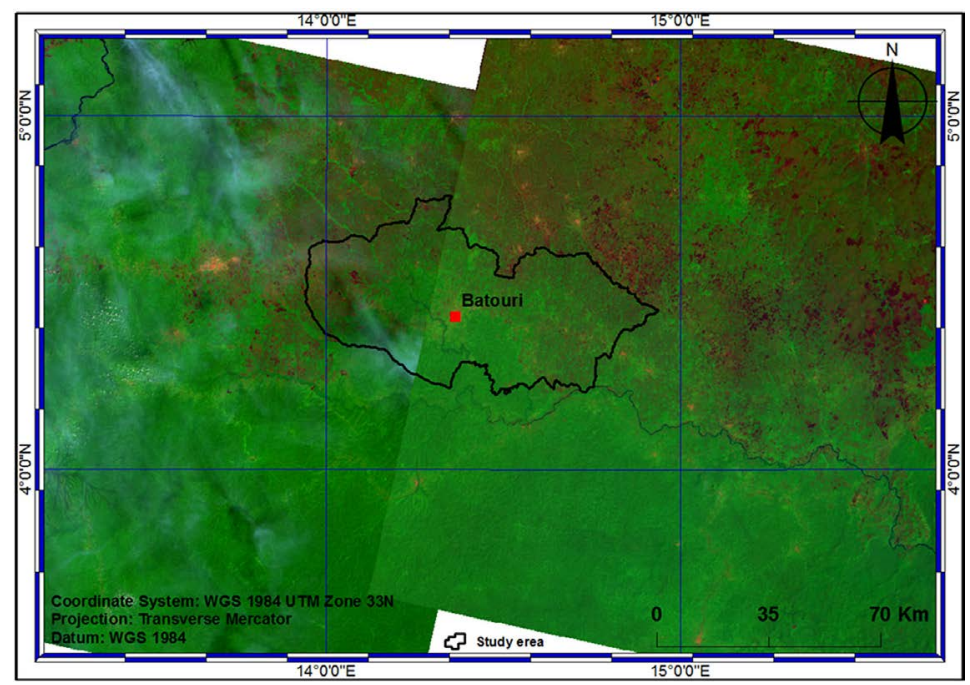

Figure 3. Mosaicked Landsat 8 OLI scenes (False color 752) covering the study area (black polygon).

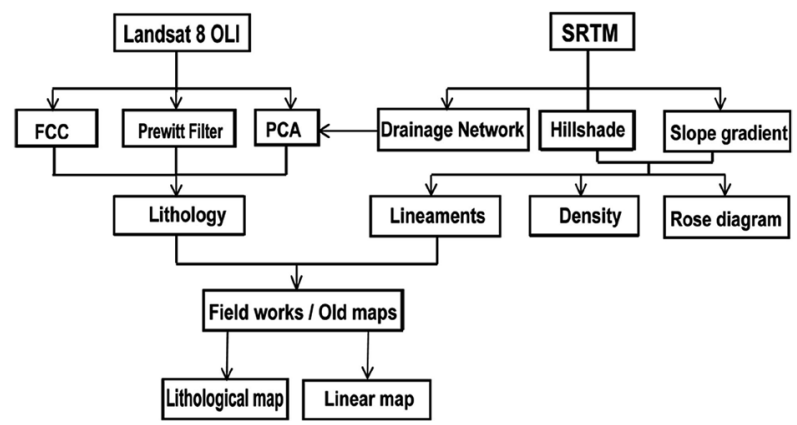

Figure 4. Summary of the methodology flowchart using Landsat 8 OLI and STRM data. 
2 to blue (B). The choice of 542 for RGB required the compute of the Optimum Index Factor (OIF) in ILWIS software; this one has a maximum value for good visual interpretation. The false color composite (FCC) image (Figure 5) obtained integrates additional information closer to the reality of the field, that reveals the structure of the soil and clearly allows the discrimination of the geologic features referring to the vegetation in view of relationship between vegetation-soil-geology.

\section{2) Directional filtering and PCA}

The directional filters are used to highlight or to mask the specific characteristics of the image based on their frequency linked to the texture. We used directional filters, in particular, Prewitt filter shown in Table 1. Prewitt's algorithm 7 $\times 7$ matrix filters is an operator used in image processing for the detection of contours. In this study, the Prewitt filter was done on 542 colored image and panchromatic image (band 8). The Principal Component Analysis (PCA) was carried out in order to overcome the strong redundancy of multi-band images and to improve the contrast of the image (Figure 6). The PCA generates a series of new image bands that are generally expressed in lowering order of variability. Thus, the first principal component represents as much variation as possible in the original image data. The input image contains the seven bands with same resolution. The result of the three first components (the neo-channels PC1, PC2 and PC3) represents respectively $59.20 \% ; 28.60 \%$ and $11 \%$ (Figure 6 ) of the information contained in the original multi-spectral image with seven bands. Later on, a supervised classification of a PCA image was run (Figure 7), the signature file was created using PCA values of co-located pixels with field polygons (fieldwork).

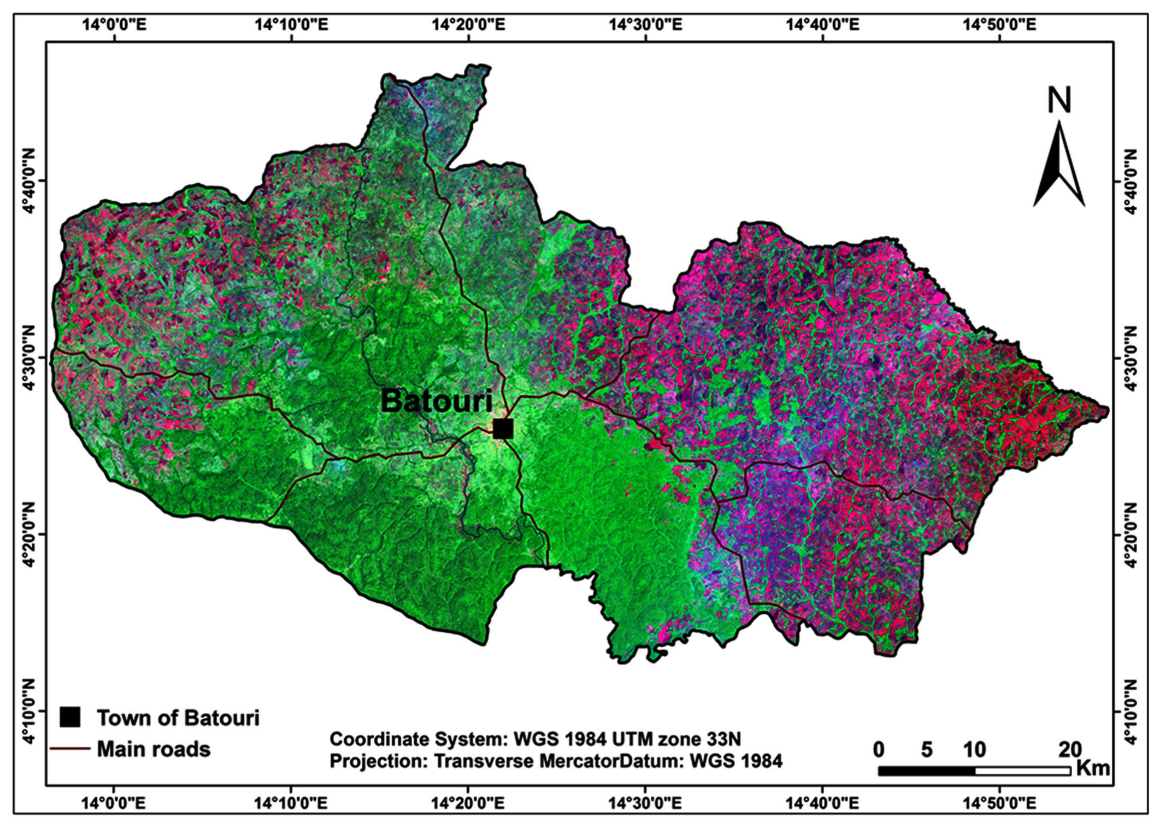

Figure 5. Landsat 8 OLI 542 (RGB) false color composite of study area. The purple color represents dry soils in savanna and green color for moist soils under the forest. 


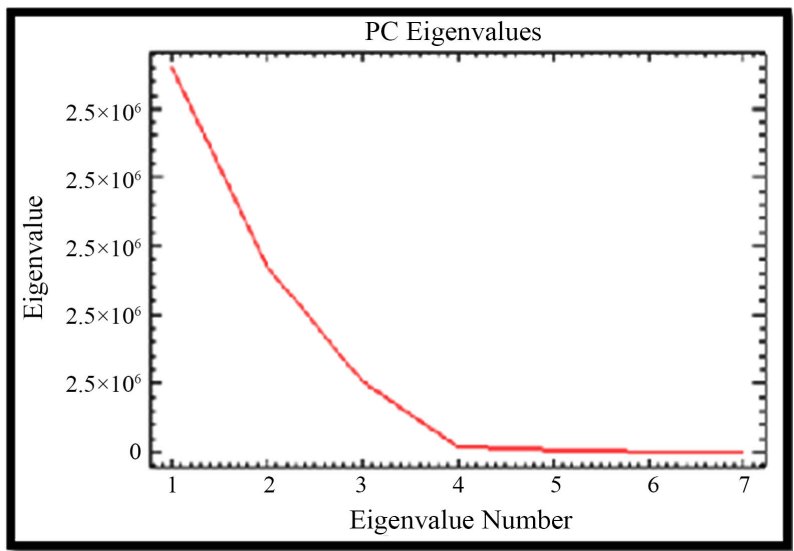

Figure 6. Scree plot of eigenvalues

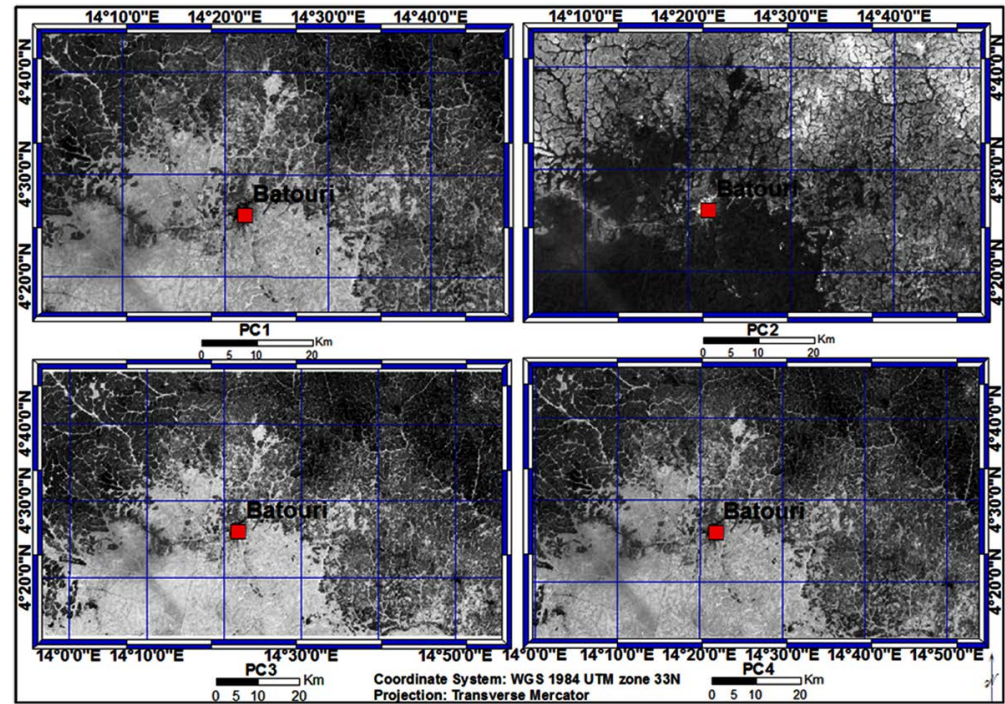

Figure 7. Four first neo-channels PC1, PC2 (inverted), PC3, and PC4 in greyscale, representing respectively the decreasing of the information contained in the original multi-spectral image.

Table 1. The Matrix of Prewitt filter.

\begin{tabular}{lllllll}
\hline 1 & 1 & 1 & 1 & 1 & 1 & 1 \\
1 & 1 & 1 & 1 & 1 & 1 & 1 \\
1 & 1 & 1 & 1 & 1 & 1 & 1 \\
-1 & -2 & -3 & -7 & 1 & 1 & 1 \\
-1 & -2 & -3 & -3 & 1 & 1 & 1 \\
-1 & -2 & -2 & -2 & 1 & 1 & 1 \\
-1 & -1 & -1 & -1 & 1 & 1 & 1 \\
\hline
\end{tabular}

\subsubsection{Lineament Study}

To detect structural features from SRTM data, the image was imported into the ArcGIS software. The SRTM-DEM technique for structural interpretation is on the basis of hillshade image with various elevations and slope gradient. The pro- 
cedure was performed in two steps: First, the shaded relief images were created for various sun azimuths and angles of $045^{\circ}, 135^{\circ}, 225^{\circ}$ and $315^{\circ}$ (Figures $8(\mathrm{a})$-(d)). Indeed, areas perpendiculars to the sun angle are illuminated the most while the areas with high angle or greater than $90^{\circ}$ are shaded. Secondly, slope gradient maps were generated through stretching by histogram equalizer into 10 intervals and display with a gradual greyscale from white (lower values) to black. The histogram is a little bit homogeneous and the values for mean, standard deviation and median are almost same. Then, visual and manual interpretations were required to extract geologic lineaments.

\subsection{Field Investigation Techniques}

During the field surveys, we explored the outcrops and described rock outcrops at regional and mesoscale. Set of tools mainly including GPS and geologic compass has been very useful for measuring of the geological structures such as foliation, shistosity, boudins, and fractures. This step also permitted to collect the representative samples of each rock types, to explore the mining sites in each landscape, and then to take the locations of gold occurrences using the GPS. The outcrops in this area were accessed through the roads and cattle tracks, footpaths, rivers and stream channels. The vegetation encountered is typically a wooded savanna at north, the forest galleries along rivers and streams and dense forest at South.

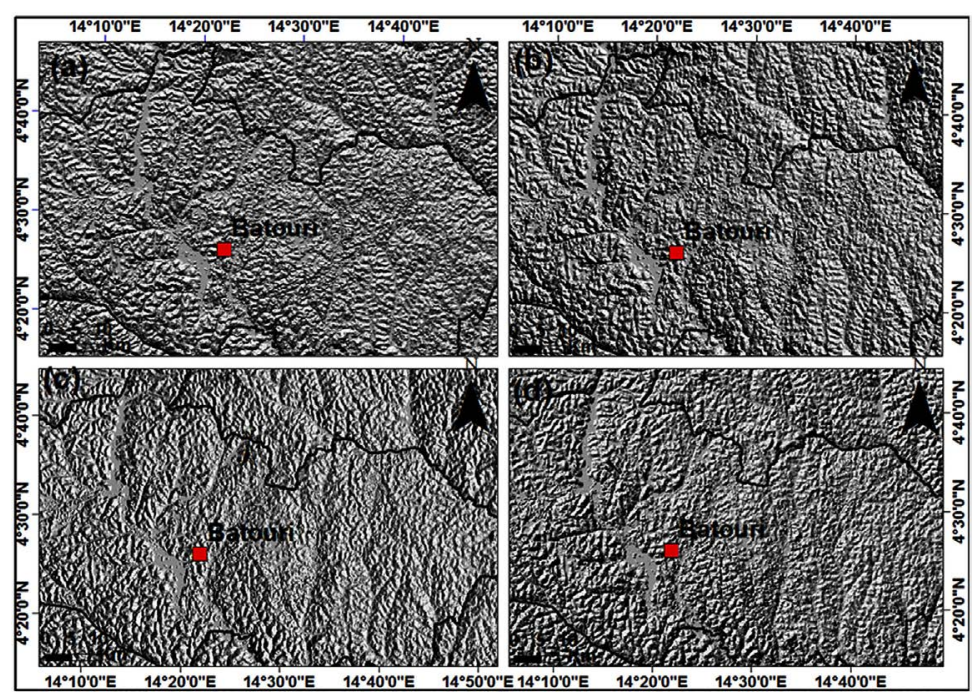

Figure 8. Hillshade images with varying sun azimuth and angle used to enhance structural determination of lineaments in the area. (a) sun illumination azimuth at $45^{\circ}$; (b) Sun illumination azimuth at $135^{\circ}$; (c) Sun illumination azimuth at $225^{\circ}$; (d) Sun illumination azimuth at $315^{\circ}$ (black line represents contours of study erea).

\section{Results}

\subsection{Field Observations}

From field Petrographic descriptions referring to the existing works [3] is shown that, geology of Batouri is much variable. Deformed and non-deformed Plutonic rocks are found throughout the study area. Deformed rocks include migmatic 
gneisses, orthogneisses and mylonites, whereas undeformed rocks are constituted of tonalite, diorite, granodiorite, syeno-monzo-granite, alkaline granite, (Figure 9(a), Figures 9(c)-(g)). At the mapping scale, four main rock types' namely tonalite, granodiorite, syeno-monzo-granite and alkaline granite have been distinguished and mapped. The main mineralization styles consist of 1) quartz vein deposits and stockwerks (Figure 9(b)) and 2) disseminated deposits which constitute the primary gold deposits; 3) the alluvial placers and 4) eluvial placers are secondary gold deposits. Most of the artisanal mining sites such as Kambele, Mongonnam, Tikondi, Pandi, Tapare and Mama are situated at secondary placers. The field data based on the relative chronology of the different structural elements observed on the outcrops and the geometric relationship between these structural features revealed that, the area of Batouri was affected by three phases of deformation.

The early deformation D1 phase is associated to two events: firstly, the migmatization and granitization of old gneiss basement, and the SW-NE and S-N trending faults associated with intrusion of aplite dykes; secondly the emplacement of plutonic rocks recorded all along the tectonic evolution. In places,
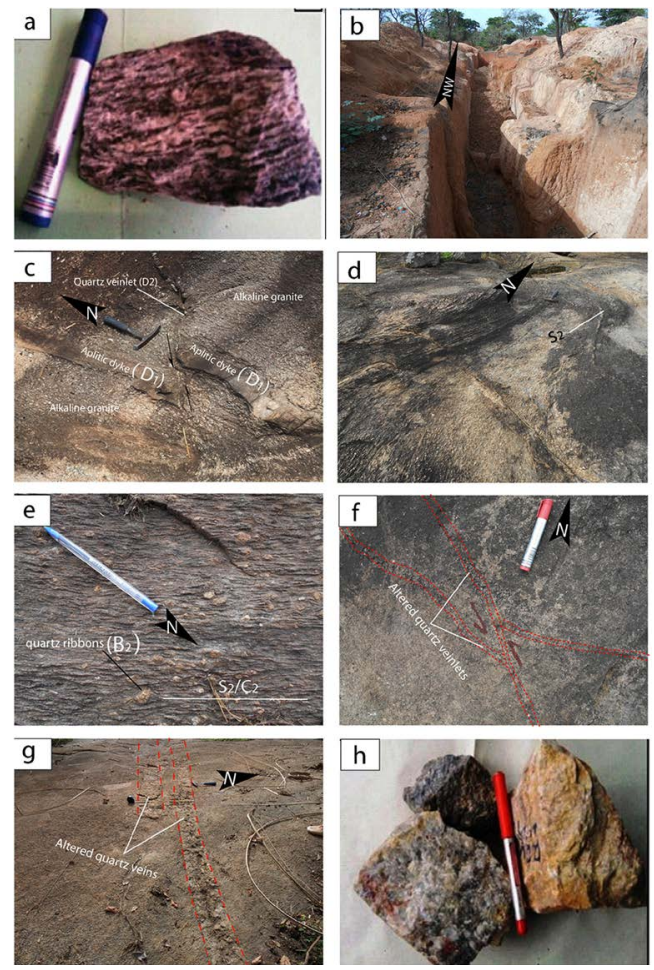

Figure 9. Field photographs of some rock samples and outcrops, artisanal mining and deformation structures at Batouri. (a) Mylonite sample from Ndongmembe. (b) NW-SE-trending tunnel of mineralized vein extracted by artisanal miners at Pandi. (c) Outcrop of sub-horizontal alkaline granite intruded by an aplite dyke and crosscuted by a quartz vein at Nguemo. (d) $\mathrm{C}_{2}$-band along Protomylonite at Ndongmembe. (e) mylonitic foliation in outcrop of mylonite at Ndongmembe. (f) Truncated and sinistral displaced altered quartz veins at Pandi, supposed mineralized but obscured by weathering. (g) NW-SE-trending altered quartz veins at Pandi. (h) Varieties of mineralized quartz veins from Batouri. 
the aplitic granite intrutions occur as a set of parallel near-horizontal dykes which appear to define local foliation and assuming to represent the last phase of magmatic activity at Batouri. This phase shows both the spatial association of ductile and brittle structures marked by migmatitic foliation and aplitic granite dykes (Figure 9(c)). That phase was recorded by migmatites of Ndoumimbe, Nguemo and Goura II. In general, the foliation $S_{1}$ is locally outlined by sub-horizontal aplitic granite dykes intruded mostly in alkaline granites and migmatites. Three main orientations of $S_{1}$ foliation have been identified: 1) a major NE-SW direction with average dips of $\left.35^{\circ} \mathrm{NW}, 2\right) \mathrm{E}-\mathrm{W}$ to $\mathrm{N}$ and 3) NNE-SSW direction with flat dip. As for L1 lineation, it's commonly mineral lineation, defined by quartzo-feldspathic elongation with main direction N-S and oblique plunge $\left(\sim 35^{\circ}\right)$ to the Nord. Thus, the intersection of foliation plants have yield to the facts of a regional $\mathrm{P}_{1}$ fold axes $\left( \pm \mathrm{N} 170^{\circ} / 30^{\circ}\right)$.

The D2 deformation phase is defined by SW-NE trending ductile-brittle sinistral shear zones associated with gold mineralization, which mainly cuts granodiorite, syeno-monzo-granite and alkaline granite plutons. These shear zones are Brittle-ductile shear zones formed under intermediate conditions (fault zones + deformation + metamorphism). That phase locally combined mylonitic foliation, schistosity and also associated with secondary NW-SE-trending faults. In field, $\mathrm{S}_{2}$ mylonitic foliation, $\mathrm{S}_{2}$ schistosity and $\mathrm{C}_{2}$ sinistral shear band (Figure 9(d)) were observed in mylonites of Ngouengan, protomylonites of Ndoumimbe, granodioritic gneisses of Dimako I, syeno-monzo-granites of Tikondi and granodiorites of Kambele. The $\mathrm{S}_{2}$ mylonitic foliation is outlined by a compositional banding and mostly trends NE-SW rarely WNW-ESE with sub-vertical dip toward NW. The transposition of $\mathrm{S}_{1}$ by $\mathrm{C}_{2}$ thrust was observed at scale of outcrop in alkaline granite of Ndoumimbe and Djira. The lenticular porphyroclasts of feldspars $\left(B_{2}\right)$ associated to sinistral $S_{2} / C_{2}$ structures are developed on both the mafic (biotite, amphibole) and the quartzo-feldspathic layers (Figure 9(e)).

Brittle aspect of this phase consist of fractures marked by the $\mathrm{N} 030^{\circ}, \mathrm{N} 060^{\circ}$, $\mathrm{N} 090^{\circ}, \mathrm{N} 135^{\circ} \mathrm{C}_{2}$ quartz veins shear planes which displace and truncate aplite veins with sinistral motion and subvertical dip (Figure $9(\mathrm{f})$ ). These veins vary from $5 \mathrm{~cm}$ to $0.5 \mathrm{~m}$ in thickness and are discontinuous (Figure $9(\mathrm{~g})$ ), they consist essentially of white, rose and smoky quartz varieties, as well as carbonates (Figure 9(h)).

The D3 phase is mainly brittle and composed of fractures including barren quartz veins, pegmatite dykes and dry joints with all azimuthal direction, they are mostly encountered in Bougogo, Amidobi, Goura II, Nkolbomo, Tikondi Djoko, Gbakine, Mbosso and Takobe.

\subsection{Lineament Investigation}

Directional filters applied on a Shuttle Radar DEM image to ease lineaments identification and manual extraction show distinct structural features (including faults, shears and fractures). Only features that could correspond to geological 
structures were considered (Figure 10(a)). From the satellite imageries processed, a total of 1669 lineament features and major faults were identified, extracted and interpreted as geologic lineaments. The lengths vary between 1 to $21 \mathrm{~km}$ and they are oriented in all azimuth but the main directions are: N-S, NE-SW and NW-SE (Figure 10(b)). On a basis of geometric characters, three types of lineaments have been identified: 1) concordant lineaments, 2) secant lineaments and 3) upsetting lineaments (Figure 10(a) and Figure 10(c)). Concordant lineaments are parallels to certain linear faults and are interpreted as the brittle fault, Secant lineaments correspond to quartz veins in the field and upsetting lineaments correspond to the corridors of ductile deformation (shear zones). Most of the lineaments or faults correspond to the drainage network and contacts between rock units, so they are easy to trace. The topologic relationship based on the closeness between lineaments and gold signs and mining pits shows that Kambele mining sites is situated along the shear zones with a lot of lineament intersections; the Djengou mining pits is found on secant lineaments at about $0.2 \mathrm{~km}$ of shear zone, the Kambele III, Bakassi, Kapso, Amorcelin, Ngordjia and Grand bateau mining pits are situated less than $1 \mathrm{~km}$ of secant lineaments.

The technique used yields an effective and faster way to evaluate lineaments in the estimated directions. However, it requires manual features extraction, therefore subjective and laborious. There is a possibility that some lineaments are sometimes neglected. Thereafter, the lineament density map was rasterized using ArcGIS. Many of the lineament features interpreted from the various filtered were fields observed.

\subsection{Lithological Discrimination}

The colored, filtered and PCA images obtained from Landsat 8 OLI image processing show different orientations, tones, textures, linearities, and presence of water, dry and moist bare lands contrasting regions, high variability and local homogeneity zones. Drainage patterns within the study area were well identified from the images. Major drainage patterns identified in the study area are dendritic and trellis. These observations were used for interpretation and visual identification of lithology features in the study area. The supervised classification of a PCA image and drainage pattern approach combined to the colored and filtered images (as intermediate images) identified four major rock types. Through field investigations, those rock types are described as tonalite, granodiorite, syeno-monzo-granite and alkaline granite, (Figure 11). They show different structural features like foliations and lineaments. Faults or shear zones mostly represent the competent contrast between two rocks types and often correspond to a contact between two lithologies. The superposition of the lithological map obtained with GPS points of known gold occurrences shows the distribution of gold disseminated in the soil at the Batouri area. The gold signs are spatially associated with shear zones. 


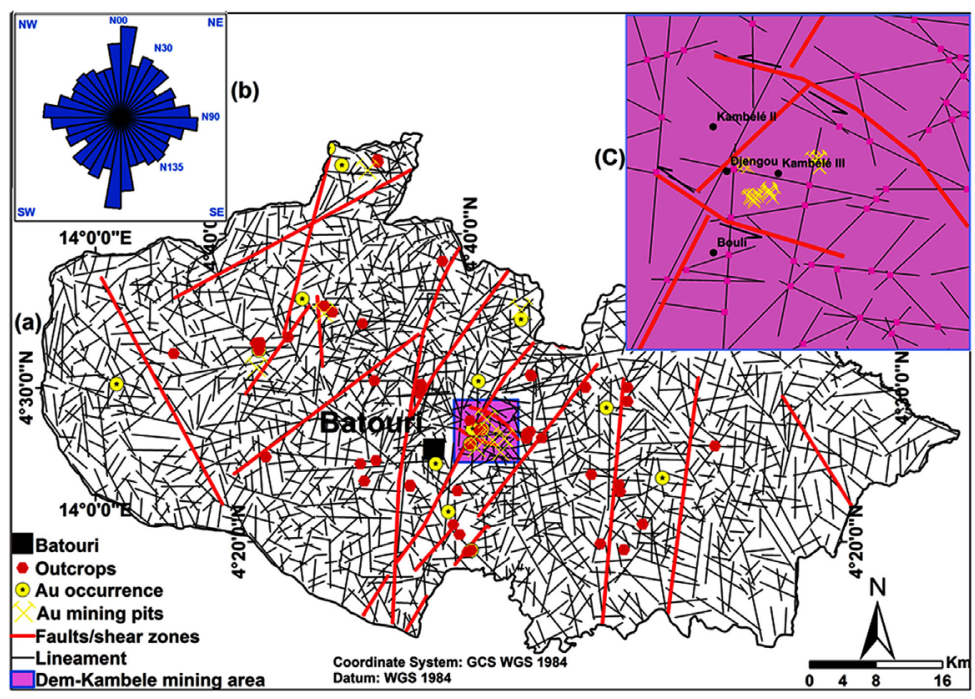

Figure 10. Linear map of the Batouri area extracted from satellite imagery. (a) Significant geological structures map. (b) Rose diagram of distribution of the directions of the lineaments. (c) Dem-Kambele mining area zoom lens.

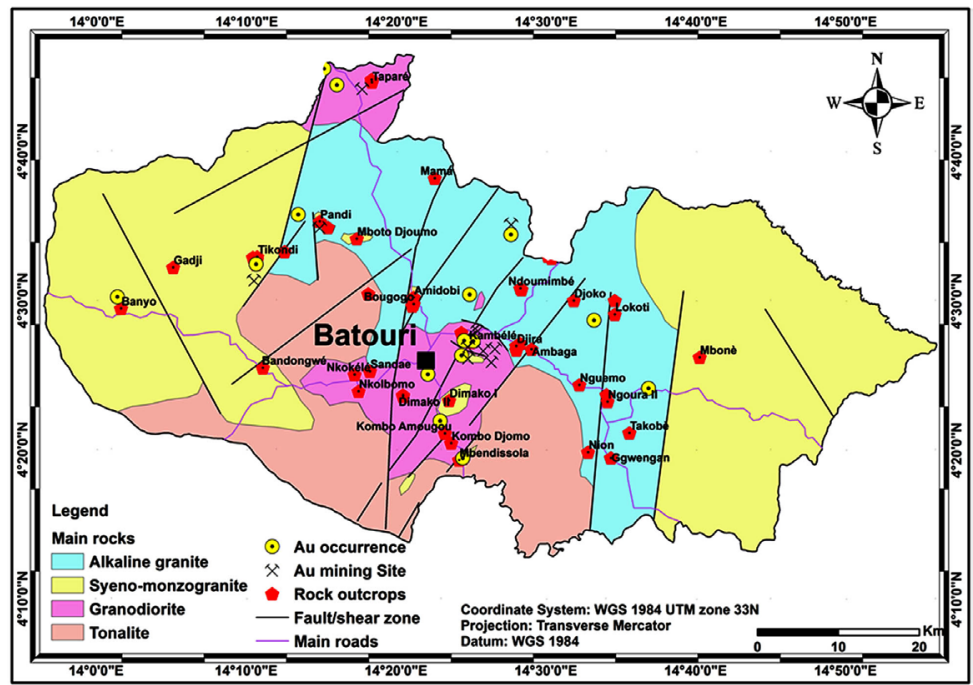

Figure 11. Batouri main lithological units map obtained from the combined field-based data, remote sensing methods and GIS tools showing the distribution of rock outcrops and gold occurrences.

\subsection{Relationship between the Density of Lineaments, Gold Occurrences, Faults/Shear Zones, Outcrops and Lodes}

Density analysis has been applied on extracted lineaments. The values of lineaments density are designated as very low $(\leq 0.78)$, low $(\leq 1.17)$, moderate $(\leq 1.57)$ high $(\leq 1.96)$ and very high $(\leq 2.35)$. The superposition of lineaments density map and faults/shear zones with field data (gold occurrences and lodes/quartz veins) of the study area shows the spatial relationship and the correlation between gold occurrences and areas of high lineaments density (Figure 12). There is a good spatial correlation between lineaments and gold mineralization. This correlation revealed that: 
- The majority of gold signs and rock outcrops are associated with faults/shear zones corresponding on field to the areas of mylonitization.

- The sector of high gold mineralization is the area with the highest lineaments density; that is what makes Kambele the biggest mining camp within the Batouri gold district where many gold mining pits are encountered.

- The gold mineralization is concentrated and disseminated; the lineaments density is well represented on field by abundance of azimuthal quartz veins. The Batouri gold District is quit vast because occurrences are found everywhere and somewhere else; researches carry out in the area have to be extended out of this area.

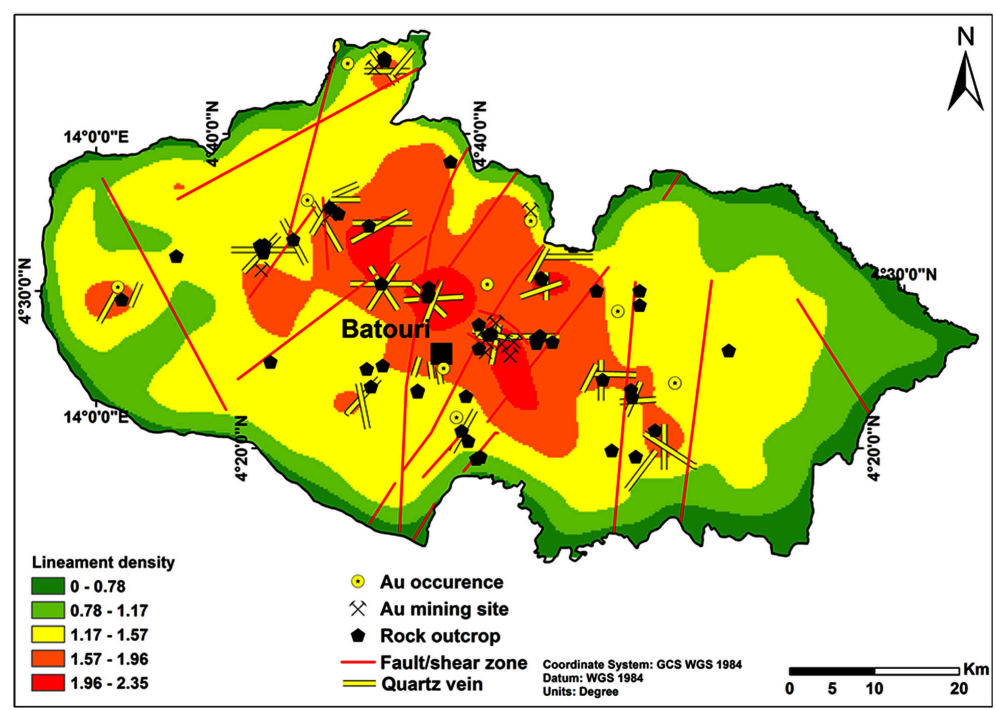

Figure 12. Correlation between lineament density, faults/shear zone, gold occurrence, lode and outcrops.

\section{Discussion}

The Batouri area has had many previous works in geological, geophysical and hydrological domain at the local [1]-[6] [22] [23] and at the regional scale [6] [23]. The current study has shown that, as mentioned by other authors, the geology of Batouri area is much variable and it is characterized by alkali granitoids highly deformed in shear zones.

Besides, the gold locations are associated with fractures and the rock outcrops are aligned along the shear zones. The lithological map of Batouri area yielded at the scale of $1 / 400.000$ cannot show all rock types encountered in field, such as migmatites and gneisses. Indeed, during the work done by [24] in central-east of Ivory Coast and [25] in Bangladesh, they respectively used the Band color composite, prewitt filter and PCA classification to map lithology using vegetation and drainage pattern as an indicator of underlying rock types in a heavily forested region. Our field observations about lithology at local and regional scale agree well with the findings of many previous studies such [1] [3] [9] in the area. The four main rock types mapped including tonalite, granodiorite, syeno-monzo- 
granite and alkaline granite represent the granitoids crosscut by shear zones, faults and quartz veins in which gold mineralization is concentrated or disseminated.

Moreover, the result obtained from lineaments studied in the area also tempts to show three types of lineaments: concordant, secant and upsetting lineaments. Most mining pits are located near secant lineaments assuming that they are the host of gold mineralization. Those observations let us propose the metallogenic model essentially based on distribution of gold according to lineaments.

In fact, during the emplacement of panafrican belt, the structural evolution at Batouri is characterized by a first episode of migmatization, granitization and the emplacement of plutonic rocks along dextral NE-SW fault during the first deformation phase D1. This phase is equivalent to the D3 dextral shear movement developed along the Central Cameroon shear zone (CCSZ). The second episode of deformation phase D2 consists to replay of dextral NE-SW faults in sinistral motion. It is marked by SW-NE trending ductile-brittle sinistral shear zones occupied by mylonites, associated with gold mineralization, which mainly cut granodiorite, syeno-monzo granite and alkaline granite plutons. At last, the third deformation phase D3 is attributed to the intrusion of barren quartz veins and pegmatite dykes.

Likewise, the result also shows the high density of lineaments and its heterogeneity. Both first lineaments characteristic are directly dependent on the degree to which the rocks have been fractured. So, the heterogeneity of density is not linked to the rock types but, rather to the variability of brittle degree. Admitting that this study agrees with [5], it can be confirmed that the lineaments are associated with faults and it is also obvious that heavy capacity of lineaments occurrences is within the Batouri town and its surroundings. Thus, using the hypothesis that the lineaments correspond to the brittle structures in the rocks, precisely faults, dykes, quartz veins and dry joints and due to the relationship between gold occurrences and fractures, the highest density denote therefore the areas of high gold mineralization. The number of gold occurrences increases with lithology; granodiorite is the greatest gold host as seen at Kambele, then syeno-monzogranite at Tikondi and tonalite at Dimako II with neighbouring localities; the characteristics of quartz veins and altered wall rock in the Batouri gold district are suggestive of structural and lithological controlled of lode gold mineralization.

In addition, the same result shows the link between lineaments with gold occurrences and rocks outcrops. The direction of lineaments presents significant trends N-S, NE-SW and NW-SE which are similar to those well known in the geological history of Cameroon: the average direction of the Tchollire fault (N50E), the direction of the hot line of Cameroon (N30E), the Adamaoua fault (N70E), the direction of the Benoue ditch (NW-SE), Lom Series (NW-SE), the Sanaga Fault (N70E) and Central Cameroon shear zone (ENE-WSW), confirming the genesis of lineaments during the compressive force between the collision between the mobile belt and the northern edge of the Congo Craton. Meanwhile, 
only NE-SW $\left(\mathrm{N} 035^{\circ}\right)$ and NW-SE has been interpreted by [2] and [3] as approximate trend of auriferous shear zones and quartz veins. The occurrence of gold signs concentrated along the shear zones could be explained by two geologic phenomenons, either metamorphism/plutonism or often to brittle/ductile deformation. Likewise, the alignment of rock outcrops could be associated with the orogeny of pan-African granitic intrusions (pan-African granitoids). From all those geological data, it is obvious that the Batouri gold is epigenetic gold set in place in orogenic setting.

\section{Conclusion}

The Batouri gold District has a rich geological potential favorable to host gold mineralization. The remote sensing by an analysis of a Landsat 8 OLI and a Shuttle Radar DEM permitted to generate the geological data such as main lithological facies map, structural lineaments map and density map as the potential targets for the best characterization and understanding of the geology associated to the gold mineralization in the Batouri area. The study produced and combined the geological data of the Batouri gold District area using satellite imageries, GIS processing and field work in order to characterize it and to contribute to the better knowledge of its geological setting. From the interpretation of the geomatics data combined to the field data in GIS, it's shown that: the geology of Batouri gold District varies a lot and has a large variety of lithological facies. The gold mineralization hosts consist of four main granitic rocks namely: tonalite, granodiorite, syeno-monzogranite and alkaline granite associated to quartz veins. The fault and shear structures defined on field by the presence of mylonites crosscut all those main lithological units; the three lineaments types identified 1) concordant lineaments, 2) secant lineaments and 3) upsetting lineaments well correspond on the field to the faults, shear zones, dykes, quartz veins or dry joints. The number of gold occurrences increases with lithology, several mining pits are found in granodiorite of kambele, the occurrence of gold signs is concentrated along the shear zones with a lot of lineament intersections and the high gold mineralization zones corresponds to the area of highest lineaments density. From those observations, we propose the metallogenic model essentially based on distribution of high gold occurrences according to lineaments. Thus, all these data are suggestive of tectonic and lithological control of lode gold mineralization in the Batouri gold district. It's conclusive that the Batouri gold deposit is epigenetic gold set emplaced in orogenic setting. The resulting geological information's can be used for the mining exploration or gold panning in the area, neighboring Mining districts and for the better management of geological resources by local township.

\section{Acknowledgements}

This paper is a part of the first author's Ph.D thesis in preparation. The first author wishes to sincerely thank all the members of "I love Geomatics" at Yaoundé 
for their contribution on his training in Remote Sensing and GIS. We gratefully acknowledge the reviewers for their critical and constructive comments on the manuscript. The authors would like to thank Haskandi Kalaza Josué for having improved the English's quality of the manuscript.

\section{Conflicts of Interest}

The authors declare no conflicts of interest regarding the publication of this paper.

\section{References}

[1] Suh, C.E., Lehmann, B. and Mafany, G.T. (2006) Geology and Geochemical Aspects of Lode Gold Mineralization at Dimako-Mboscorro, SE Cameroon. Geochemistry. Exploration, Environment, Analysis, 6, 295-309.

https://doi.org/10.1144/1467-7873/06-110

[2] Suh, C.E. (2008) Sulphide Microchemistry and Hydrothermal Fluid Evolution in Quartz Veins, Batouri Gold District (Southeast Cameroon). Economic Geology Unit, University of Buea, Buea, Cameroon.

[3] Assaah, V.A. (2010) Lode Gold Mineralisation in the Neoproterozoic Granitoids of Batouri Southeastern Cameroon. Clausthal University of Technology, ClausthalZellerfeld, Germany, 202p.

[4] Assaah, V.A., Zoheir, B., Lehmann, B., Freid, D., Burgess, R. and Suh, C.E. (2015) Geochemistry and Geochronology of the $\sim 620$ Ma Gold-Associated Batouri Granitoids, Cameroon. International Geology Review, 57, 1485-1509.

https://doi.org/10.1080/00206814.2014.951003

[5] Vishiti, A., Suh, C.E., Lehmann, B., Egbe, J.A. and Shemang, E.M. (2015) Gold Grade Variation and Particle Microchemistry in Exploration Pits of the Batouri Gold District, SE Cameroon. Journal of African Earth Sciences, 111, 1-13. https://doi.org/10.1016/j.jafrearsci.2015.07.010

[6] Ngoumou, P.C., Marie-Louise Clotilde, O.A., Alou Marcelin, B.B., Joseph Antoine, W.K., Olivier Ulrich Igor, O.A. and Mbarga, T.N. (2016) Evidence by Multi-Scale Analysis of Lineaments Derived from Gravity Anomalies in the Batouri Area (Eastern-Cameroon). International Journal of Science and Research, 5, 2319-7064. https://doi.org/10.21275/v5i2.NOV161206

[7] Scanvic, J.Y., Delpont, G. and King, C. (1985) Structural and Geobotanical Contribution of Remote Sensing to Exploration of Hidden Deposits in Brittany (France). BRGM, Service Géologique National, Rapport Final du projet CEE MSM 037F, 151 p.

[8] Van Schmus, W.R., Oliveira, E.P., da Silva Filho, A.F., Toteu, S.F., Penaye, J. and Guimarães, I.P. (2008) Proterozoic Links between the Borborema Province, NE Brazil, and the Central African Fold Belt. Geological Society, London, Special Publications, 294, 69-99. https://doi.org/10.1144/SP294.5

[9] Ngako, V., Affaton, P., Nnange, J.M. and Njanko, T. (2003) Pan-African Tectonic Evolution in Central and Southern Cameroun: Transpression and Transtension during Sinistral Shear Movements. Journal of African Earth Sciences, 36, 207-214. https://doi.org/10.1016/S0899-5362(03)00023-X

[10] Ngako, V., Jegouzo, P. and Nzenti, J.P. (1991) Le Cisaillement Centre Camerounais. Rôle structural et géodynamique dans l'orogenèse panafricaine. Compte Rendu de P Académie des Sciences, 315, 457-463. 
[11] Dumont, J.F. (1986) Identification par télédétection de l'accident de la Sanaga (Cameroun): Sa position dans le contexte des grands accidents d'Afrique Centrale et de la limite nord du craton congolais. Géodynamique, 1, 13-19.

[12] Toteu, S.F., Penaye, J. and Djomani, Y.P. (2004) Geodynamic Evolution of the Pan-African Belt in Central Africa with Special Reference to Cameroon. Canadian Journal of Earth Sciences, 41, 73-85. https://doi.org/10.1139/e03-079

[13] Tanko-Njiosseu, E.L., Nzenti, J.P., Njanko, T., Kapajika, B. and Nédélec, A. (2005) $\mathrm{New}$ U-Pb Zircon Ages from Tonga (Cameroon): Coexisting Eburnean-Transamazonian $(2.1 \mathrm{Ga})$ and Pan-African $(0.6 \mathrm{Ga})$ Imprints. Comptes Rendus Geosciences, 337, 551-562. https://doi.org/10.1016/j.crte.2005.02.005

[14] Toteu, S.F., Penaye, J., Deloule, E., Van Schmus, W.R. and Tchameni, R. (2006) Diachronous Evolution of Volcanosedimentary Basins North of the Congo Craton: Insights from U-Pb Ion Microprobe Dating of Zircons from the Poli, Lom and Yaoundé Groups (Cameroon). Journal of African Earth Sciences, 44, 428-442. https://doi.org/10.1016/j.jafrearsci.2005.11.011

[15] Gazel, J. and Gérard, G. (1954) Carte géologique de reconnaissance du Cameroun au 1/500 000, feuille Batouri-Est avec notice explicative. Memoir. Direction Mines Géologie, Yaoundé, Cameroon.

[16] Tchakounté, J., Eglinger, A., Toteu, S.F., Zeh, A., Nkoumbou, C., Mvondo-Ondoa, J., Penaye, J., de Wit, M. and Barbey, P. (2017) The Adamawa-Yadé Domain, a Piece of Archaean Crust in the Neoproterozoic Central African Orogenic Belt (Bafia Area, Cameroon). Precambrian Research, 299, 210-229. https://doi.org/10.1016/j.precamres.2017.07.001

[17] Saha-Fouotsa, A.N., Vanderhaeghe, O., Barbey, P., Eglinger, A., Tchameni, R., Zeh, A., Tchunte, P.F. and Nomo, E.N. (2019) The Geologic Record of the Exhumed Root of the Central African Orogenic Belt in the Central Cameroon Domain (MbéSassa-Mbersi Region). Journal of African Earth Sciences, 151, 286-314. https://doi.org/10.1016/j.jafrearsci.2018.12.008

[18] Kamwa, N., Tchakounte, J.N., Nkoumbou, C., Owona, S., Tchouankoue, J.-P. and Mvondo Ondoa, J. (2018) Petrology and Geochemistry of the Yoro-Yangben PanAfrican Granitoid Intrusion in the Archaean Adamawa-Yade Crust (Sw-Bafia, Cameroon). Journal of African Earth Sciences, 150, 401-414.

https://doi.org/10.1016/j.jafrearsci.2018.11.004

[19] Castaing, C., FeyBesse, J.L., Thieblemont, D., Triboulet, C. and Chevremont, P. (1994) Palaeogeographical Reconstructions of the Pan-African/Brasiliano Orogen: Closure of an Oceanic Domain or Intracontinental Convergence between Major Blocks. Precambrian Research, 69, 327-344. https://doi.org/10.1016/0301-9268(94)90095-7

[20] Toteu, S.F., Van Schmus, R.W., Penaye, J. and Michard, A. (2001) New U-Pb and Sm-Nd Data from North Central Cameroon and Its Bearing on the Pre-Pan-African History of Central Africa. Precambrian Research, 108, 45-73. https://doi.org/10.1016/S0301-9268(00)00149-2

[21] Ngako, V., Affaton, P. and Djonfang, E. (2008) Pan-African Tectonics in Northwestern Cameroon: Implication for the History of Western Gondwana. Gondwana Research, 14, 509-522. https://doi.org/10.1016/j.gr.2008.02.002

[22] Ngatcha, R.B., Okunlola, O.A., Suh, C.E., Eben Mboe, E.R. and Fuanya, C. (2018) A Review of Granitoid-Related Gold Mineralization Styles and Characteristics of the Neoproterozoic Eastern Gold Districts, Cameroon and the Role of Fluid Inclusion Studies in Elucidating the Genesis. Journal of Geosciences and Geomatics, 6, 138 146. 
[23] Zanga-Amougou, A., Ndougsa-Mbarga, T., Meying, A., Yufenyu Layu, D., Bikoro-Bi-Alou, M. and Manguelle-Dicoum, E. (2014) 2.5D Modeling of Crustal Structures along the Eastern Cameroon and Western Central African Republic Derived from Finite Element and Spectral Analysis Methods. Geophysica, 49, 75-97.

[24] Ouattara, G., Barthélemy Koffi, G. and Yao, A.K. (2012) Contribution des images satellitales Landsat 7 ETM+ à la cartographie lithostructurale du Centre-Est de la Côte d'Ivoire (Afrique de l'Ouest). International Journal of Innovation and Applied Studies, 1, 61-75.

[25] Mahmood, T.H., Hasan, K. and Akhter, S.H. (2018) Lithologic Mapping of a Forested Montane Terrain from Landsat 5 TM Image. Geocarto International, 14, 750768. https://doi.org/10.1080/10106049.2018.1434688 